\title{
Carbon Dioxide-mediated Decomposition of Hydrogen Peroxide in Alkaline Solutions
}

\author{
By José A. Navarro, Miguel A. De la Rosa, Mercedes Roncel \\ and Francisco F. de la Rosa* \\ Departamento de Bioquímica, Facultad de Biología y CSIC, Universidad de Sevilla, \\ Apartado 1095, Sevilla, Spain
}

Received 24th June, 1983

\begin{abstract}
Rapid hydrogen peroxide decomposition in aerated alkaline solutions is described, the maximum rate being attained at $\mathrm{pH}$ values between 11.5 and 11.7 , where the peroxide $\left(\mathrm{p} K_{\mathrm{a}}=11.7\right)$ is $c a .50 \%$ unprotonated. The reaction proceeds with the release of protons and is strictly dependent upon the continuous presence of carbon dioxide, but not of carbonate anions, in the peroxide solutions. The following two-step mechanism is proposed: (1) formation of percarbonic acid $\left(\mathrm{H}_{2} \mathrm{CO}_{4}\right)$ by condensation of $\mathrm{CO}_{2}$ with the undissociated peroxide $\left(\mathrm{H}_{2} \mathrm{O}_{2}\right)$ and (2) reduction of the acid by perhydroxyl anions $\left(\mathrm{HO}_{2}^{-}\right)$.
\end{abstract}

In previous papers ${ }^{1,2}$ describing a photochemical system for hydrogen peroxide production with flavin as photosensitizer, semicarbazide as electron donor and oxygen as electron acceptor, we found an anomalous and drastic decrease in the efficiency of the photoproduction of $\mathrm{H}_{2} \mathrm{O}_{2}$ at $\mathrm{pH} c a$. 12, and the stability of $\mathrm{H}_{2} \mathrm{O}_{2}$ was found to be a function of $\mathrm{pH}$. Hydrogen peroxide decomposition is a very complex reaction and it has been studied extensively for many years. The decomposition may take place spontaneously, but it is accelerated by the presence of catalysts such as metal ions $(\mathrm{Fe}, \mathrm{Cu}, \mathrm{Mn}),{ }^{3-5}$ metal oxide $\left(\mathrm{OsO}_{4}\right),{ }^{6}$ metal complexes (metallotetraphenylporphyrins, iron-EDTA) ${ }^{7,8}$ or enzymes (catalase, peroxidases). Two mechanisms have been proposed for the spontaneous decomposition of $\mathrm{H}_{2} \mathrm{O}_{2},{ }^{3-5,9}$ but neither has been readily accepted.

This paper deals with the effect of carbon dioxide on the decomposition of $\mathrm{H}_{2} \mathrm{O}_{2}$ in alkaline solutions, which, to the best of our knowledge, has not been described previously.

\section{EXPERIMENTAL}

The kinetics and rates of the decomposition of hydrogen peroxide were studied in a cylindrical glass vessel of $2 \mathrm{~cm}$ diameter. The hydrogen peroxide (30\%, analytical grade, Merck) solutions were prepared immediately prior to the experiments at a final concentration of $20-22 \mathrm{mmol} \mathrm{dm}^{-3}$ in $10 \mathrm{~cm}^{3}$ of doubly distilled water.

The $\mathrm{H}_{2} \mathrm{O}_{2}$ solutions had a continuous stream of air, nitrogen $(99.99 \%)$, oxygen $(99.9 \%)$ or carbon dioxide $(99.5 \%$ ) passed through them, the flow rate of the gas stream being controlled by a Century Vit flowmeter and maintained at $0.1 \mathrm{dm}^{3} \mathrm{~min}^{-1}$. In some experiments, the air was previously passed through a saturated $\mathrm{Ba}(\mathrm{OH})_{2}$ solution to remove $\mathrm{CO}_{2}$.

The $\mathrm{pH}$ of the $\mathrm{H}_{2} \mathrm{O}_{2}$-containing solutions, especially that of the unbuffered ones, was continuously monitored during the experiments with a Radiometer $\mathrm{pH}$-meter and kept at the desired value by addition of a small amount of concentrated $\mathrm{NaOH}$ or $\mathrm{HCl}$ solution.

The $\mathrm{H}_{2} \mathrm{O}_{2}$ content was determined by enzymatic reduction of the peroxide with $o$-dianisidine, as described previously, ${ }^{10}$ the absorbance of the complex so formed being measured at $440 \mathrm{~nm}$ with a Pye Unicam SP8-100 spectrophotometer.

All the chemicals were reagent grade and used without further purification. 


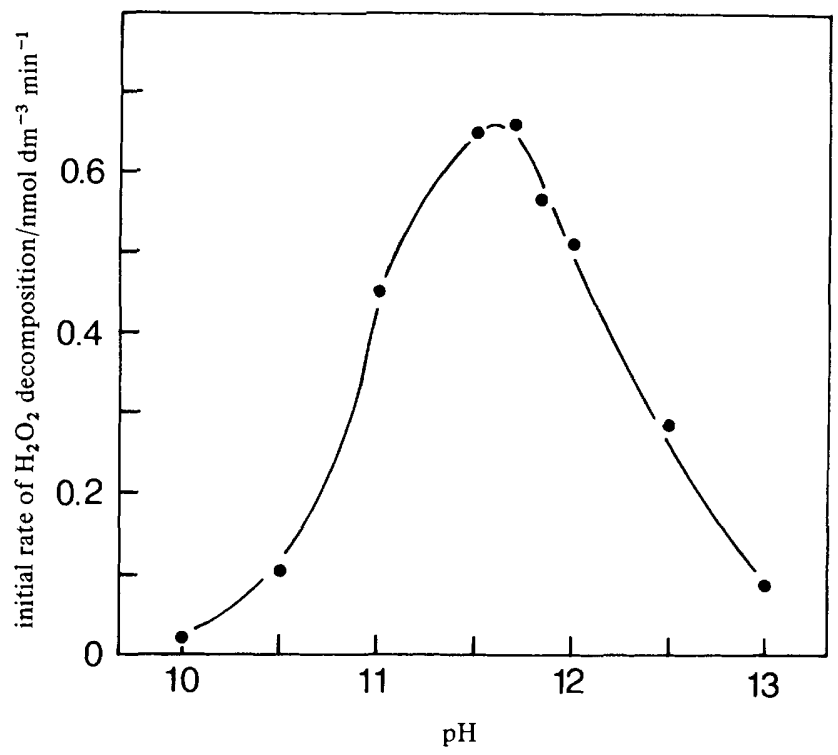

Fig. 1. Dependence on $\mathrm{pH}$ of decomposition of hydrogen peroxide in aerated solutions. $10 \mathrm{~cm}^{3}$ solutions containing $20 \mathrm{mmol} \mathrm{dm}-3 \mathrm{H}_{2} \mathrm{O}_{2}$ at the indicated $\mathrm{pH}$ were continuously aerated at a flow rate of $0.1 \mathrm{dm}^{3} \mathrm{~min}^{-1}$, the peroxide content being measured as described in the experimental section. The solutions were buffered either with borate $(\mathrm{pH} 10.0,10.5$ and 11.0) or with phosphate (pH 11.0, 11.5, 11.7, 12.0 and 12.5) at a final concentration of $0.6 \mathrm{~mol} \mathrm{dm}^{-3}$. At pH 13.0 the solution was unbuffered but contained $0.1 \mathrm{~mol} \mathrm{dm}^{-3} \mathrm{NaOH}$. In all cases the pH was continuously monitored throughout the experiments with a $\mathrm{pH}$-meter and adjusted when necessary.

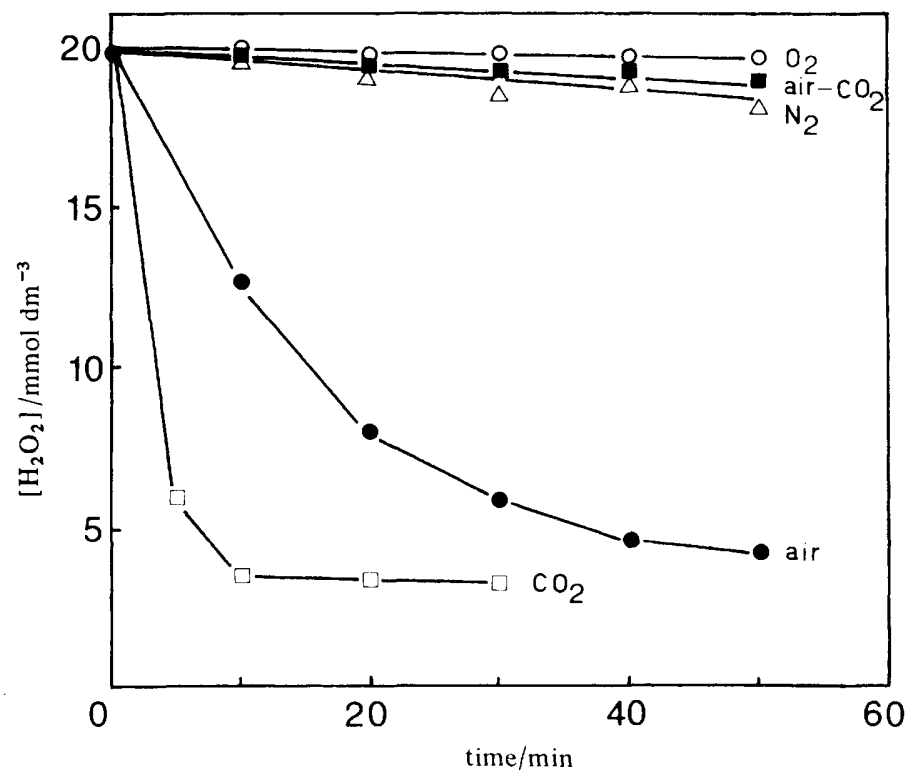

Fig. 2. Kinetics of decomposition of hydrogen peroxide at $\mathrm{pH} 12$ under different gases. Nitrogen, oxygen, carbon dioxide or air either with or without $\mathrm{CO}_{2}$ were passed through unbuffered solutions containing $20 \mathrm{mmol} \mathrm{dm} \mathrm{mm}^{-3} \mathrm{H}_{2} \mathrm{O}_{2}$ in a final volume of $10 \mathrm{~cm}^{3}$. The $\mathrm{pH}$ was initially adjusted to 12 and maintained constant throughout each experiment. The $\mathrm{H}_{2} \mathrm{O}_{2}$ content was measured at the indicated times. 


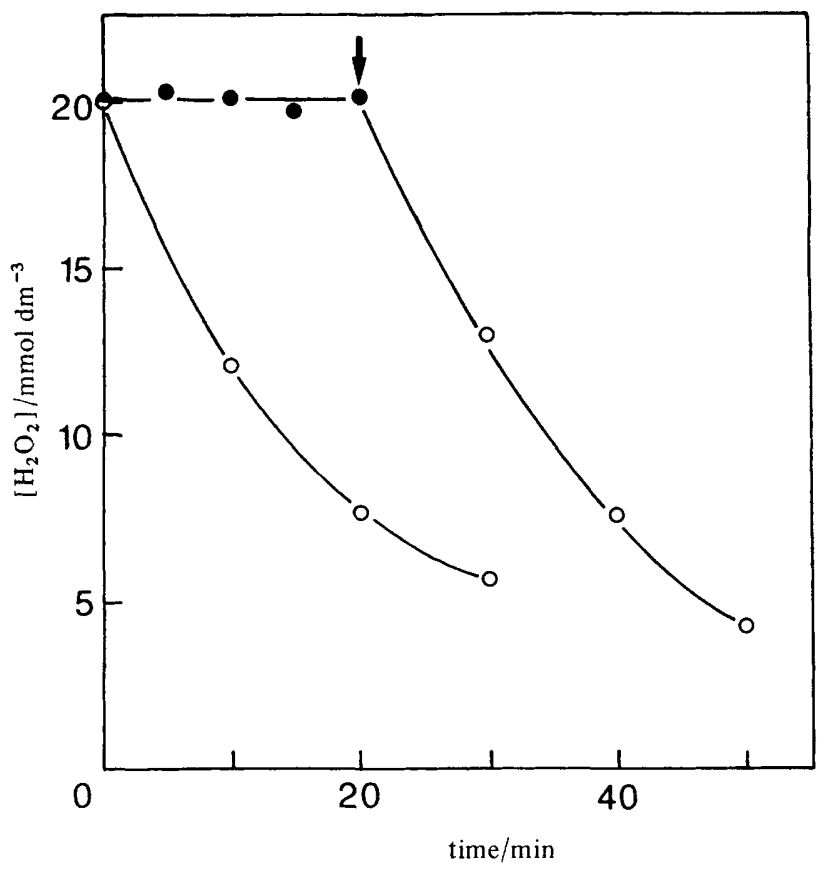

Fig. 3. Requirement of carbon dioxide (but not of carbonate anions) for decomposition of hydrogen peroxide at $\mathrm{pH} 12$. Either air $(\mathrm{O})$ or $\mathrm{CO}_{2}$-free air $(O)$ were passed through $10 \mathrm{~cm}^{3}$ solutions containing $20 \mathrm{mmol} \mathrm{dm}^{-3} \mathrm{H}_{2} \mathrm{O}_{2}$ and $0.5 \mathrm{~mol} \mathrm{dm}^{-3}$ carbonate buffer at $\mathrm{pH} 12$. The arrow indicates the moment when the air stream, initially free of $\mathrm{CO}_{2}$, was passed directly through the peroxide solution without passing through the $\mathrm{Ba}(\mathrm{OH})_{2}$ solution. The $\mathrm{pH}$ was maintained at 12 throughout the experiments. The $\mathrm{H}_{2} \mathrm{O}_{2}$ content was determined at the indicated times.

\section{RESULTS AND DISCUSSION}

As shown in fig. $1, \mathrm{H}_{2} \mathrm{O}_{2}$ decomposed rapidly in aerated solutions containing the peroxide at a concentration of $20 \mathrm{mmol} \mathrm{dm}^{-3}$, the maximum rate $\left(0.7 \mathrm{mmol} \mathrm{dm}^{-3} \mathrm{~min}^{-1}\right)$ being attained at $\mathrm{pH}$ values between 11.5 and 11.7. Significant decomposition of $\mathrm{H}_{2} \mathrm{O}_{2}$ was not observed at $\mathrm{pH}<10$ or $>13$. As the first $\mathrm{p} K_{\mathrm{a}}$ value of $\mathrm{H}_{2} \mathrm{O}_{2}$ is 11.7 , coinciding with the $\mathrm{pH}$ region at which $\mathrm{H}_{2} \mathrm{O}_{2}$ decomposition reached a maximum, it seems likely that the presence of both peroxide molecules and perhydroxyl anions is necessary for the process to take place, in accordance with the uncatalysed mechanism reported previously. ${ }^{5,9}$

However, when the $\mathrm{H}_{2} \mathrm{O}_{2}$-containing solutions, at $\mathrm{pH} \mathrm{12,} \mathrm{had} \mathrm{either} \mathrm{oxygen} \mathrm{or}$ nitrogen passed through them, no decomposition of $\mathrm{H}_{2} \mathrm{O}_{2}$ was observed. In contrast, when carbon dioxide was used, the peroxide decomposed at a very high rate (see fig. 2). $\mathrm{H}_{2} \mathrm{O}_{2}$ decomposition did not occur when the solutions had $\mathrm{CO}_{2}$-free air, obtained by passing the air stream through a saturated solution of barium hydroxide, passed through them (see also fig. 2). From this we deduced the effect of carbon dioxide on the decomposition of $\mathrm{H}_{2} \mathrm{O}_{2}$ in alkaline solutions.

Note, however, that in aqueous solutions $\mathrm{CO}_{2}$ is diluted and hydrated to $\mathrm{H}_{2} \mathrm{CO}_{3}$, quickly losing one or two protons, depending on the $\mathrm{pH}$ of the solution, as shown in the following simplified reactions

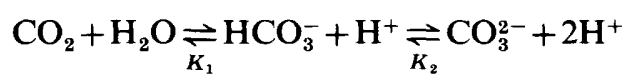


where $\mathrm{p} K_{1}$ and $\mathrm{p} K_{2}$ are 6.3 and 10.3 , respectively. ${ }^{11}$ As the $\mathrm{CO}_{2}$-dependent decomposition of $\mathrm{H}_{2} \mathrm{O}_{2}$ was observed to be especially high at $\mathrm{pH} 11-12$, where almost all the $\mathrm{CO}_{2}$ is present as $\mathrm{CO}_{3}^{2-}$ anions, it was investigated whether decomposition of $\mathrm{H}_{2} \mathrm{O}_{2}$ occurs in the presence of such anions. The results obtained are shown in fig. 3, where it can be seen that peroxide decomposition at $\mathrm{pH} 12$ does not take place in the presence of carbonate unless the solutions have air containing $\mathrm{CO}_{2}$ passed through them. If the carbonated solutions of $\mathrm{H}_{2} \mathrm{O}_{2}$ had $\mathrm{CO}_{2}$-free air passed through them, the decomposition reaction was much slower. These findings mean that $\mathrm{CO}_{2}$, but not carbonate anions, is the species responsible for catalysing the decomposition of $\mathrm{H}_{2} \mathrm{O}_{2}$.

In view of these results, it appears that one possible explanation would be the oxidation of $\mathrm{HO}_{2}^{-}$by percarbonic acid, previously formed by reaction of $\mathrm{CO}_{2}$ with $\mathrm{H}_{2} \mathrm{O}_{2}$ :

$$
\begin{aligned}
\mathrm{CO}_{2}+\mathrm{H}_{2} \mathrm{O}_{2} & \rightarrow \mathrm{H}_{2} \mathrm{CO}_{4} \\
\mathrm{H}_{2} \mathrm{CO}_{4}+\mathrm{HO}_{2}^{-} & \rightarrow \mathrm{O}_{2}+\mathrm{H}_{2} \mathrm{O}+\mathrm{HCO}_{3}^{-} .
\end{aligned}
$$

The last reaction can be visualized as taking place as the result of a nucleophilic attack of perhydroxyl anions on percarbonic acid, as shown in the following scheme:

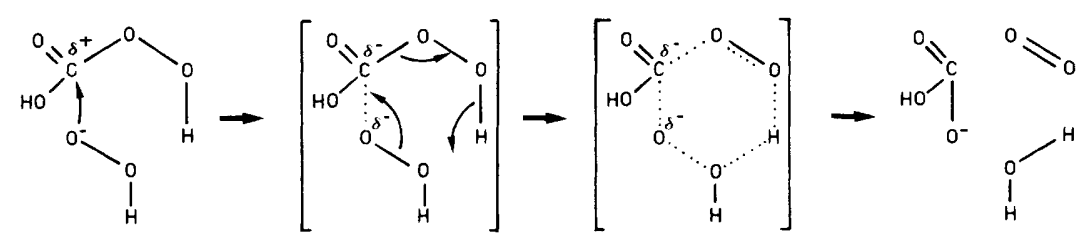

According to the proposed mechanism, and as we were working at $\mathrm{pH} 12$, the decomposition reaction must involve the release of protons, since the bicarbonate anion, at that $\mathrm{pH}$, will lose its proton to a form carbonate anion. The total reaction,

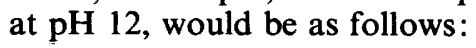

$$
\mathrm{CO}_{2}+\mathrm{H}_{2} \mathrm{O}_{2}+\mathrm{HO}_{2}^{-} \rightarrow \mathrm{O}_{2}+\mathrm{H}_{2} \mathrm{O}+\mathrm{CO}_{3}^{2-}+\mathrm{H}^{+}
$$

In order to check this hypothesis, the set of experiments shown in fig. 4 was carried out. The $\mathrm{pH}$ of unbuffered solutions containing $\mathrm{H}_{2} \mathrm{O}_{2}$, initially adjusted to 12 , decreased, as the peroxide was decomposing, at a higher rate than that of similarly treated solutions without $\mathrm{H}_{2} \mathrm{O}_{2}$ in which the $\mathrm{pH}$ decrease was only due to $\mathrm{CO}_{2}$ contained in the air being passed through the solutions.

These results support the above mechanism but contradict that described previously by Abel, ${ }^{12}$ in which the decomposition of the peroxide proceeds through the uncatalysed reaction of perhydroxyls with undissociated peroxide molecules

$$
\mathrm{H}_{2} \mathrm{O}_{2}+\mathrm{HO}_{2}^{-} \rightarrow \mathrm{H}_{2} \mathrm{O}+\mathrm{O}_{2}+\mathrm{OH}^{-}
$$

and brings about the concomitant release of hydroxyl anions.

We thank Prof. Losada (Seville) for helpful advice and criticism and Prof. Munuera (Seville) and Mulders (Brussels) for stimulating discussions. This work was aided by 


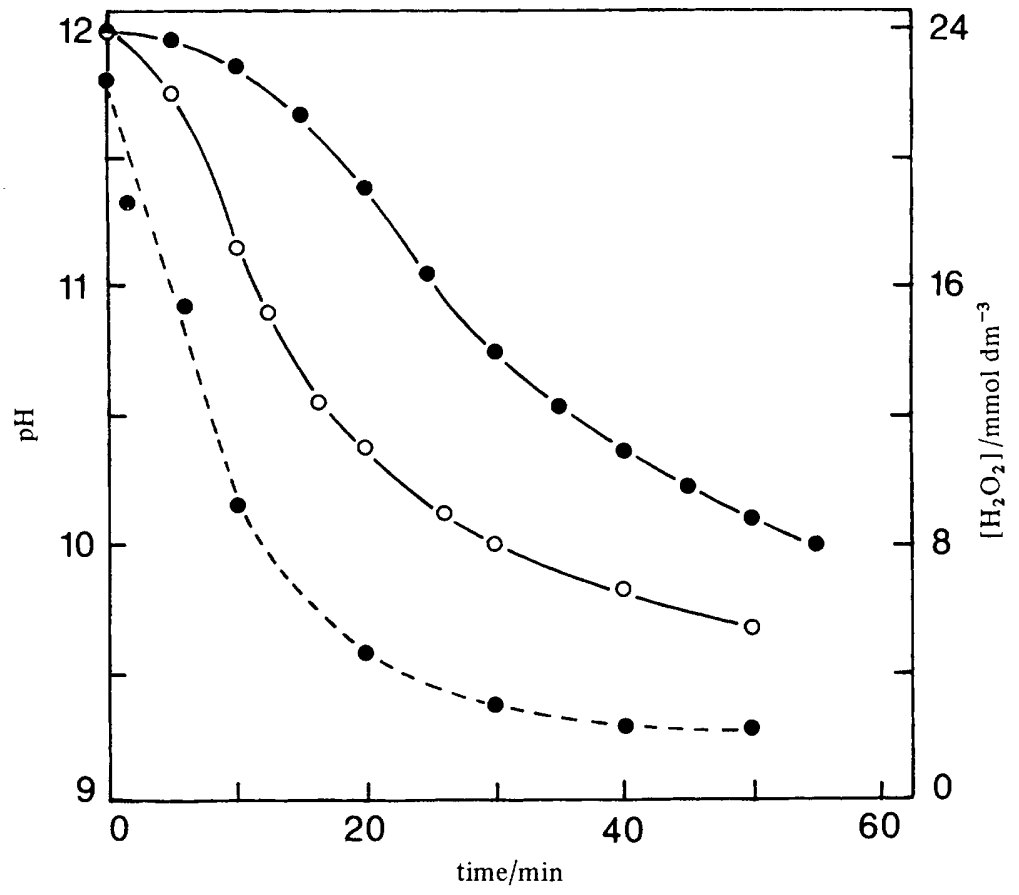

Fig. 4. Decrease of $\mathrm{pH}$ during the $\mathrm{CO}_{2}$-mediated decomposition of hydrogen peroxide in unbuffered solutions. A $10 \mathrm{~cm}^{3}$ solution containing $22 \mathrm{mmol} \mathrm{dm}^{-3} \mathrm{H}_{2} \mathrm{O}_{2}$, whose $\mathrm{pH}$ was initially adjusted to 12 by addition of $\mathrm{NaOH}$, was continuously aerated at a flow rate of $0.1 \mathrm{dm}^{3} \mathrm{~min}^{-1}$. Its $\mathrm{H}_{2} \mathrm{O}_{2}$ content $(--.-)$ and $\mathrm{pH}(\mathrm{O}-\mathrm{O})$ were measured at the indicated times. The $\mathrm{pH}$ of another aerated solution containing only $10 \mathrm{~cm}^{3}$ of distilled water was adjusted to 12 and its decrease also plotted $(-0)$.

grants from Centro de Estudios de la Energía (Spain), Comisión Asesora de Investigación (Spain) and Philips Research Laboratories (The Netherlands). M.R. was a fellow of the Ministerio de Industria y Energía (Spain).

1 M. A. De la Rosa, J. A. Navarro, M. Hervás, F. F. De la Rosa and M. Losada, Proceedings of I Congreso Ibérico de Energia Solar ISES, in press.

2 M. A. De la Rosa, J. A. Navarro, F. F. De la Rosa and M. Losada, Photobiochem. Photobiophys., 1983, 5, 93.

3 D. K. Jaiswal, R. N. Ram and B. B. Prasad, Z. Phys. Chim., 1982, 263, 74.

4 H. W. Richter and W. H. Waddell, J. Am. Chem. Soc., 1982, 104, 4630.

5 O. Spalek, J. Balej and I. Paseka, J. Chem. Soc., Faraday Trans. 1, 1982, 78, 2349.

6 L. Nagy, Z. M. Galbács, L. J. Csányi and L. Horváth, J. Chem. Soc., Dalton Trans., 1982, 859.

7 I. Mochida, A. Yasutake, H. Fujitsu and K. Takeshita, J. Phys. Chem., 1982, 86, 3468.

${ }^{8}$ E. N. Rizkalla, O. H. El-Shafey and N. M. Guindy, Inorg. Chim. Acta, 1982, 57, 199.

${ }^{9}$ F. R. Duke and T. W. Haas, J. Phys. Chem., 1961, 65, 304.

10 A. G. Fontes, F. F. De la Rosa and C. Gómez-Moreno, Photobiochem. Photobiophys., 1981, $2,355$.

11 M. G. Guerrero, C. Manzano, J. Cárdenas and M. Losada, Manometría (University Press, Seville, 1975), pp. 18-19.

12 E. Abel, Monatsh. Chem., 1952, 83, 422.

(PAPER 3/1087) 